\title{
Composite Coatings of Titanium-Aluminum Nitride for Steel against Corrosion Induced by Solid NaCl Deposit and Water Vapor at $600{ }^{\circ} \mathrm{C}$
}

\author{
M.S. Li, F.H. Wang, Y.H. Shu, W.T. Wu* \\ State Key Laboratory for Corrosion and Protection \\ Institute of Metal Research, The Chinese Academy of Sciences \\ Wencui Road 62, 110016 Shenyang, China
}

Received: September 2, 2002; Revised: September 4, 2002

\begin{abstract}
Composite coatings ( $\mathrm{Ti}, \mathrm{Al}) \mathrm{N}$ with different $\mathrm{Al}$ content were deposited on a wrought martensite steel $1 \mathrm{Cr} 11 \mathrm{Ni} 2 \mathrm{~W} 2 \mathrm{MoV}$ by reactive multi-arc ion plating. With the addition of $\mathrm{Al}$ to the coatings, the crystallographic structure of them changed from $\mathrm{B} 1 \mathrm{NaCl}$ to $\mathrm{B} 4 \mathrm{ZnS}$, the relevant hardness and adhesive strength firstly increased then decreased and their oxidation-resistance was also dramatically improved. It was indicated that the introduction of $\mathrm{Al}$ was beneficial to ( $\mathrm{Ti}, \mathrm{Al}) \mathrm{N}$ coatings against corrosion induced by $\mathrm{NaCl}(\mathrm{s})$ in wet oxygen at $600{ }^{\circ} \mathrm{C}$ as well as wet corrosion in $\mathrm{NaCl}$ solution at ambient temperature.
\end{abstract}

Keywords: coatings (Ti,Al)N, steel, synergistic effect, $\mathrm{NaCl}$, water vapor, corrosion

\section{Introduction}

It was observed that serious corrosion occurred on the compressor blades of the higher stages in a gas turbine engine after service for a long period of time in marine environment ${ }^{1,2}$. The compressor blades were made of a martensite steel $1 \mathrm{Cr} 11 \mathrm{Ni} 2 \mathrm{~W} 2 \mathrm{MoV}$ and operated at temperature around 450 600 ${ }^{\circ} \mathrm{C}$. This type of corrosion may be induced by sea water vapor or by the synergistic effect of solid salt deposits and water vapor. $\mathrm{NaCl}$ is one of the major components of salt deposits which, accumulated on the material surface in the field. In a primary study it is revealed that solid $\mathrm{NaCl}$ deposits and water vapor may have a strong synergistic effect on the corrosion of $\mathrm{Cr}$ containing steels in air at intermediate temperatures $500-600{ }^{\circ} \mathrm{C}$, as well as that of pure $\mathrm{Fe}$ and $\mathrm{Cr}$, and even $\mathrm{CrN}^{1-4}$. However, TiN showed corrosion resistance to this severe corrosive environment to some extent ${ }^{1}$. But TiN can be oxidized rapidly in air at temperature above $550^{\circ} \mathrm{C}^{5,6}$. In order to search for better coatings for $\mathrm{Cr}$ containing steel, a further study on preparation by reactive multi-arc ion plating and characterization of coatings $(\mathrm{Ti}, \mathrm{Al}) \mathrm{N}$ was performed. The main results of characteristics of the coatings are briefly summarized in this article.

*e-mail: wwt@imr.ac.cn

Presented at the International Symposium on High Temperature Corrosion in Energy Related Systems, Angra dos Reis - RJ, September 2002.

\section{Experimental Procedure}

The substrate material is the wrought martensite steel 1Cr11Ni2W2MoV (nominal compositions, wt \%: C 0.1-0.16, Cr 10.5-12, Ni 1.4-1.8, W 1.5-2, Mo 0.35-0.5, V 0.18-0.30, Mn 0.6, Si 0.6, S 0.02 and P 0.03). The samples were cut into $15 \mathrm{~mm} \times 10 \mathrm{~mm} \times 2 \mathrm{~mm}$ and ground to 1000 grit for test. Just before the experiment, the specimens were degreased in acetone, ethanol and dried in air.

Titanium aluminum nitride coatings with different $\mathrm{Al}$ content were deposited on steel specimens by a homemade reactive multi-arc ion plating facility of AIP-800-8 Coating System. Targets of pure Ti and Ti-Al alloys with different $\mathrm{Al}$ content were used respectively. Before depositing, the substrates were pre-cleaned by sputtering with Ar ions under $-1000 \mathrm{~V}$ bias voltage. The deposition parameters were listed as following: Deposition temperature $400 \sim 450{ }^{\circ} \mathrm{C}$, Total pressure 1.0 $\mathrm{Pa}, \mathrm{N}_{2}$ partial pressure 0.6 $\mathrm{Pa}$, Arc voltage $20 \mathrm{~V}$, Arc current $60 \mathrm{~A}$, D.C pulse bias voltage $-450 \mathrm{~V}$ and Duty cycle $30 \%$.

The composition of coatings was analyzed by electron probe microanalysis (CAMEBAX-MICTO). The phase constituent of coatings was characterized by X-ray diffraction 
(XRD) with $\mathrm{Cu} K_{\alpha}$ radiation. The hardness of coatings was measured by an ultra micro-hardness tester (CHX-1), which allows loading down to $10 \mathrm{~g}$. A Scratch Tester equipped with Rockwell C diamond tip was used to evaluate the adhesive strength of coatings.

The onset temperature of oxidation of coatings was measured by thermo-balance in air with a heating rate $2{ }^{\circ} \mathrm{C} /$ min from room temperature to $850{ }^{\circ} \mathrm{C}$. For corrosion test, the specimen surface was pre-placed with $\mathrm{NaCl}$ around $0.6 \mathrm{mg} / \mathrm{cm}^{2}$. Then the sample was tested at $600{ }^{\circ} \mathrm{C}$ with a thermo-balance equipped with a system of water vapor control to offer the reaction chamber an $\mathrm{O}_{2}$ flow with 12 vol. $\%$ water vapor, and the test procedures were described elsewhere $^{1,2,7}$. Potentiodynamic polarization curves were also measured with a potentiostat M273 for steel without and with coatings in $\mathrm{NaCl}$ solution.

\section{Results and Discussion}

\subsection{Crystallographic structure of coatings $(T i, A l) N$}

A series of coatings $\left(\mathrm{Ti}_{1-\mathrm{x}}, \mathrm{Al}_{\mathrm{x}}\right) \mathrm{N}$ with $\mathrm{Al}$ fraction $\mathrm{x}=0$, $0.09,0.20,0.26,0.33,0.50,0.64 ., 0.79$ and 0.92 were prepared respectively.

Figure 1 shows the XRD patterns of the coatings (Ti,Al)N with various $\mathrm{Al}$ content. It is clear that the crystallographic structure of the coatings $(\mathrm{Ti}, \mathrm{Al}) \mathrm{N}$ is $\mathrm{B} 1 \mathrm{NaCl}$ type phase TiN when $\mathrm{Al}$ fraction below $\mathrm{x}=0.65$, and above which transforms to B4 $\mathrm{ZnS}$ type phase $\mathrm{AlN}$ and at $\mathrm{x}=0.65$ it is a mixture of the two phases. The preferential orientation in coatings ( $\mathrm{Ti} \mathrm{Al}$ )N of $\mathrm{B} 1$ phase changes from (111) to (220) with the increase of $\mathrm{Al}$ content. For both $\mathrm{B} 1 \mathrm{NaCl}$ phase and wurtzite phase, the peaks of XRD pattern gradually shifted to higher diffraction angle in proportion to the $\mathrm{x}$ value, signifying that the lattice parameter decreased with the addition of Al. Ikeda et al. ${ }^{5}$ attributed the change of the lattice parameter to the substitution of $\mathrm{Al}$ atoms with the $\mathrm{Ti}$ atoms since coatings $(\mathrm{Ti}, \mathrm{Al}) \mathrm{N}$ can be considered as a solid solution in which $\mathrm{Al}$ atoms were substituted for Ti sites in B1 structure while $\mathrm{Ti}$ atoms were substituted for $\mathrm{Al}$ sites in $\mathrm{B} 4$ structure.

\subsection{Hardness and adhesive strength of coatings}

\section{$(T i, A l) N$}

The micro-hardness and critical scratch load of the coatings were represented as functions of aluminum content as shown in Fig. 2. The hardness of TiN coating with B1 structure is about $2300 \mathrm{H}_{\mathrm{v}}$. With the addition of $\mathrm{Al}$ the microhardness gradually increased up to a maximum value of $3300 \mathrm{H}_{\mathrm{v}}$ at $\mathrm{x}=0.33$. The critical scratch loads slightly increase when $x$ increased from 0 to 0.5 , and after which decreased with the increasing aluminum content. It was re- ported that the hardness of nitrides was influenced by the valence electron concentration (VEC) per unit cell ${ }^{8}$. According to the calculation, the VEC value of $\mathrm{Ti}_{0.67} \mathrm{Al}_{0.33} \mathrm{~N}$ is about 8.4. Konig et al. have reported that an optimum hardness could be obtained by valence electron concentration range

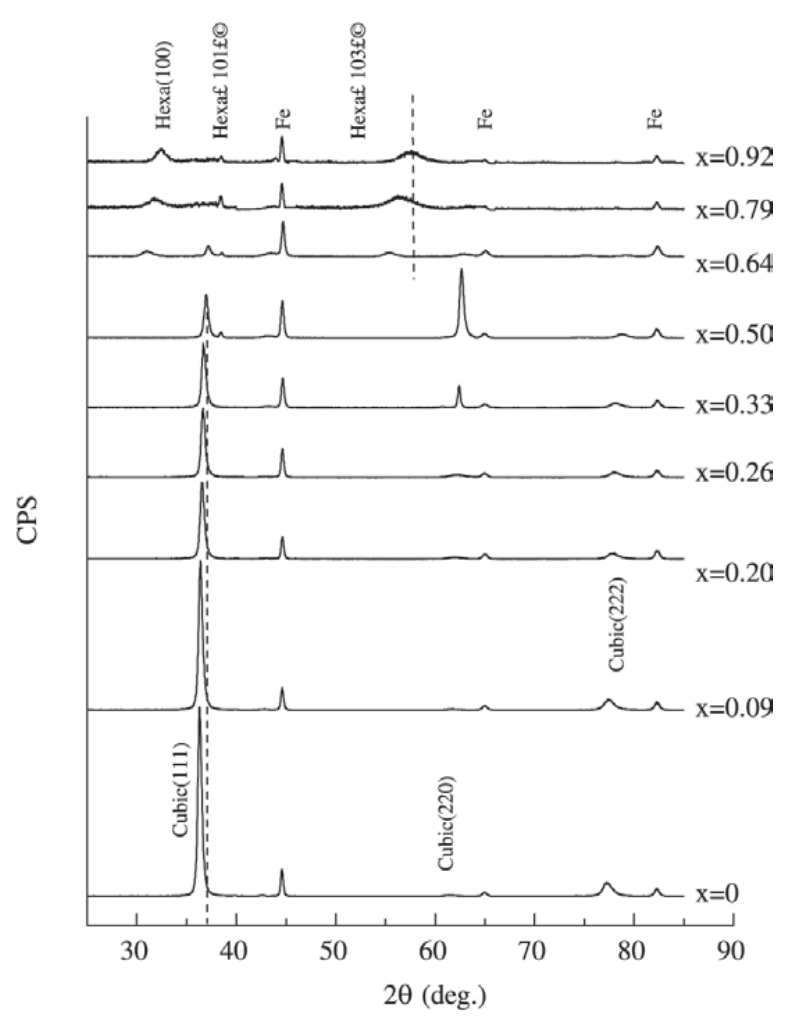

Figure1. XRD pattern of coatings $(\mathrm{Ti}, \mathrm{Al}) \mathrm{N}$ with different $\mathrm{Al}$ content.

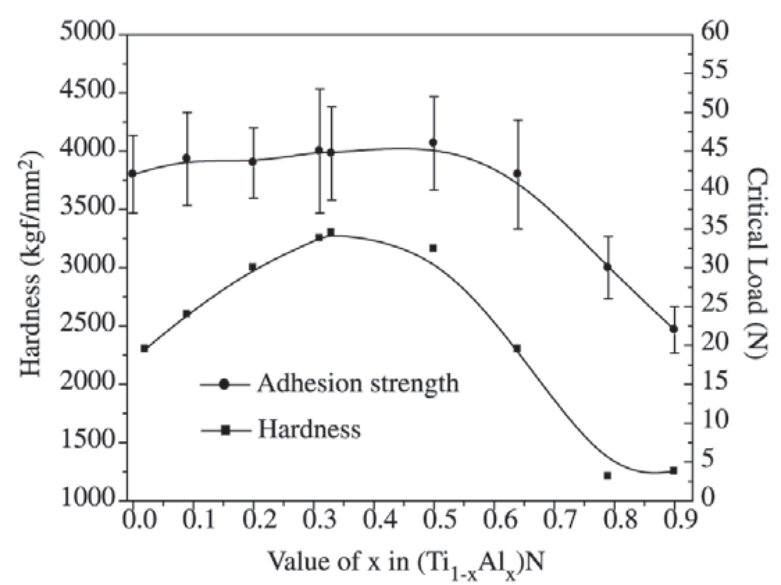

Figure 2. Hardness and adhesion strength of coatings (Ti, Al)N vs. Al content. 
of 8.4-8.6 for ternary coatings ${ }^{9}$. The hardness of (Ti,Al)N rapidly decreases when $\mathrm{x}>0.5$, which may be attributed to the phase change.

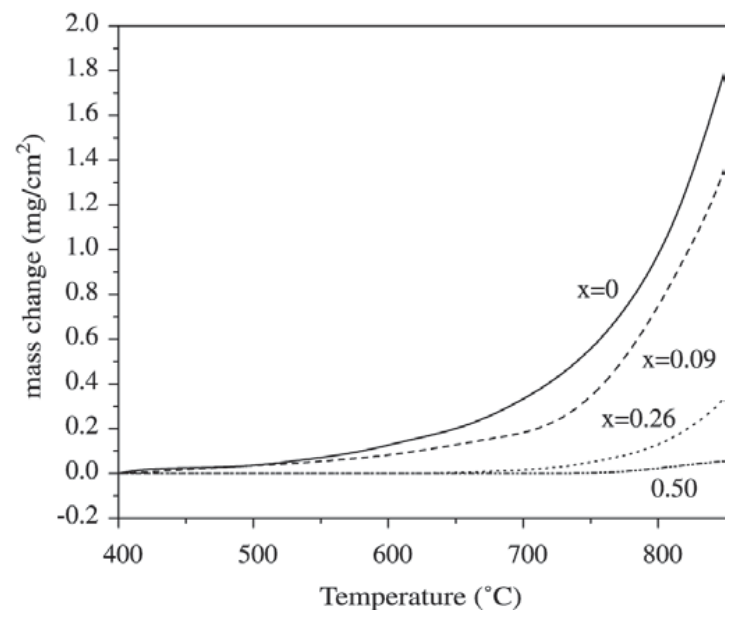

Figure 3. Oxidation curve of coatings $\left(\mathrm{Ti}_{1-\mathrm{x}} \mathrm{Al}_{\mathrm{x}}\right) \mathrm{N}$ with different $\mathrm{Al}$ contents.
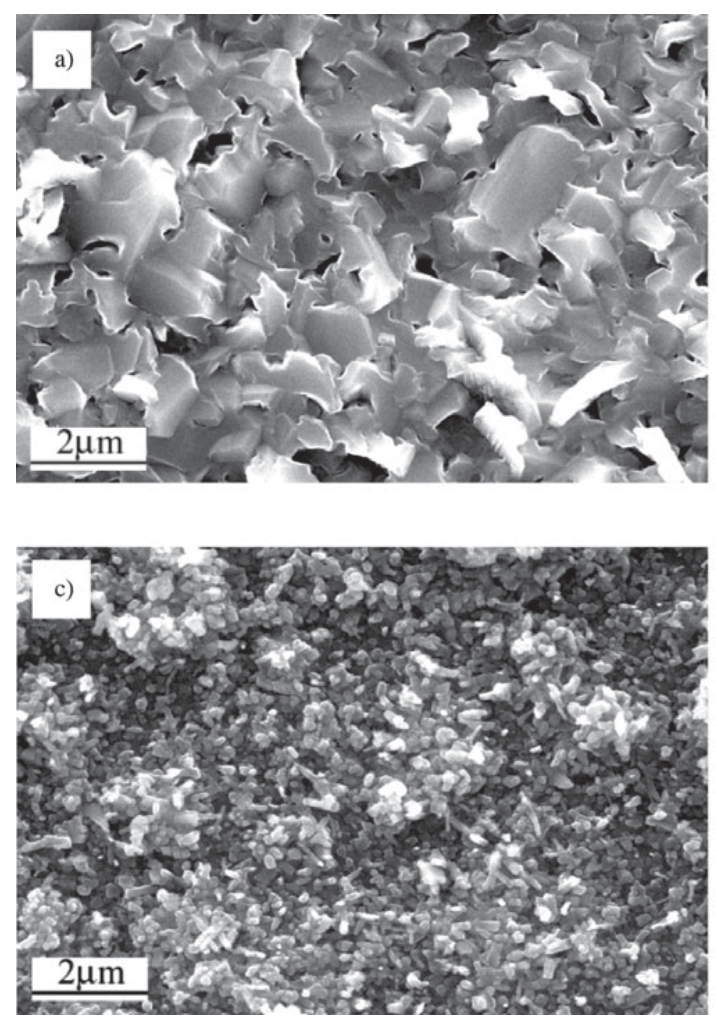

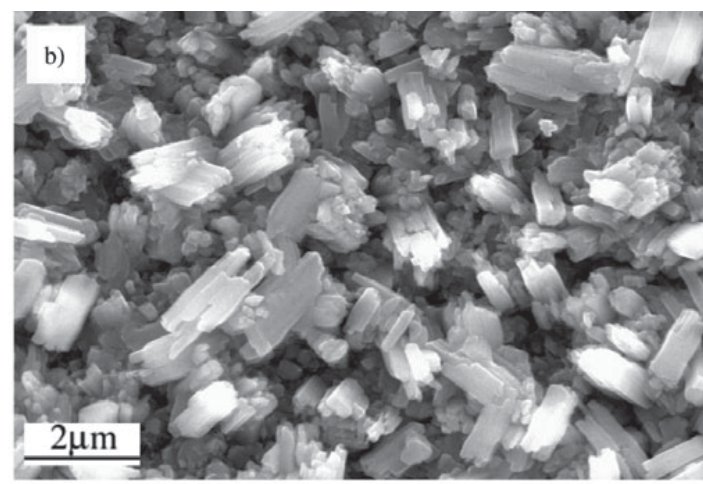

\subsection{Oxidation-resistance of coatings $(T i, A l) N$}

Oxidation curves (Fig. 3) indicated that the initiation of oxidation of TiN coating occurred at about $550^{\circ} \mathrm{C}$ and which notably increased with the increasing $\mathrm{Al}$ content and rose up to above $850{ }^{\circ} \mathrm{C}$ when $\mathrm{x}=0.5$. It was manifested from Fig. 4 that the grain size of oxide scale became finer with the increasing $\mathrm{Al}$ content. For $\mathrm{Ti}_{0.5} \mathrm{Al}_{0.5} \mathrm{~N}$ coating, no extensive change was observed after oxidation. XRD and EDX analysis indicated that an external scale of rutile $\mathrm{TiO}_{2}$ formed on TiN, but of a mixture of $\mathrm{TiO}_{2}$ and $\mathrm{Al}_{2} \mathrm{O}_{3}$ on $\mathrm{Ti}_{0.91} \mathrm{Al}_{0.09} \mathrm{~N}$ and $\mathrm{Ti}_{0.74} \mathrm{Al}_{0.26} \mathrm{~N}$, then of merely $\mathrm{Al}_{2} \mathrm{O}_{3}$ on $\mathrm{Ti}_{05} \mathrm{Al}_{05} \mathrm{~N}$. Cross section morphologies of (Ti,Al) N coatings after oxidation were shown in Fig. 5. The whole TiN coating was completely oxidized into $\mathrm{TiO}_{2}$ and $\mathrm{Cr}_{2} \mathrm{O}_{3}$ was formed on the interface between substrate and the exhaust coating. With the increase of $\mathrm{Al}$ content, the thickness of oxide scale became thinner and denser.

XPS analysis results (Fig. 6) clearly indicated that an $\mathrm{Al}_{2} \mathrm{O}_{3}$ scale was formed on the surface of $\left(\mathrm{Ti}_{0.5} \mathrm{Al}_{0.5}\right) \mathrm{N}$. This compact alumina scale seems to prevent further oxidation of the coating. Moreover, it may be suggested from results of theoretical calculation and XPS measurement that the

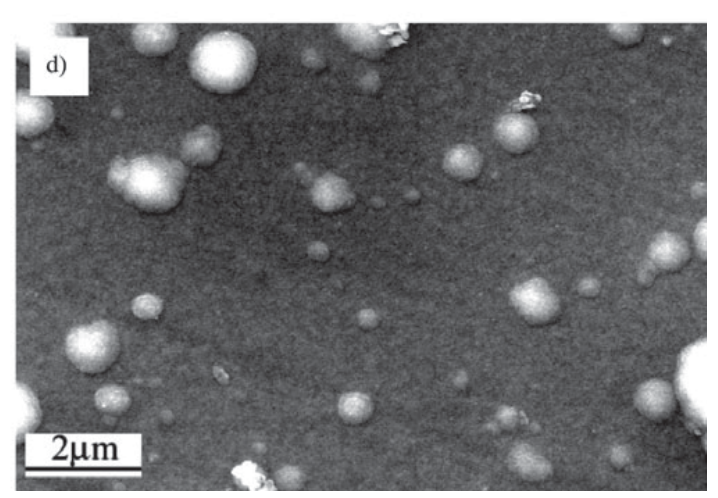

Figure 4. $\mathrm{SEM}$ topographies of coatings $\left(\mathrm{Ti}_{1-\mathrm{x}} \mathrm{Al}_{\mathrm{x}}\right) \mathrm{N}$ after oxidation $\left.\mathrm{a}\right) \mathrm{x}=0$; $\left.\left.\mathrm{b}\right) \mathrm{x}=0.09 ; \mathrm{c}\right) \mathrm{x}=0.26$; $) \mathrm{x}=0.50$. 

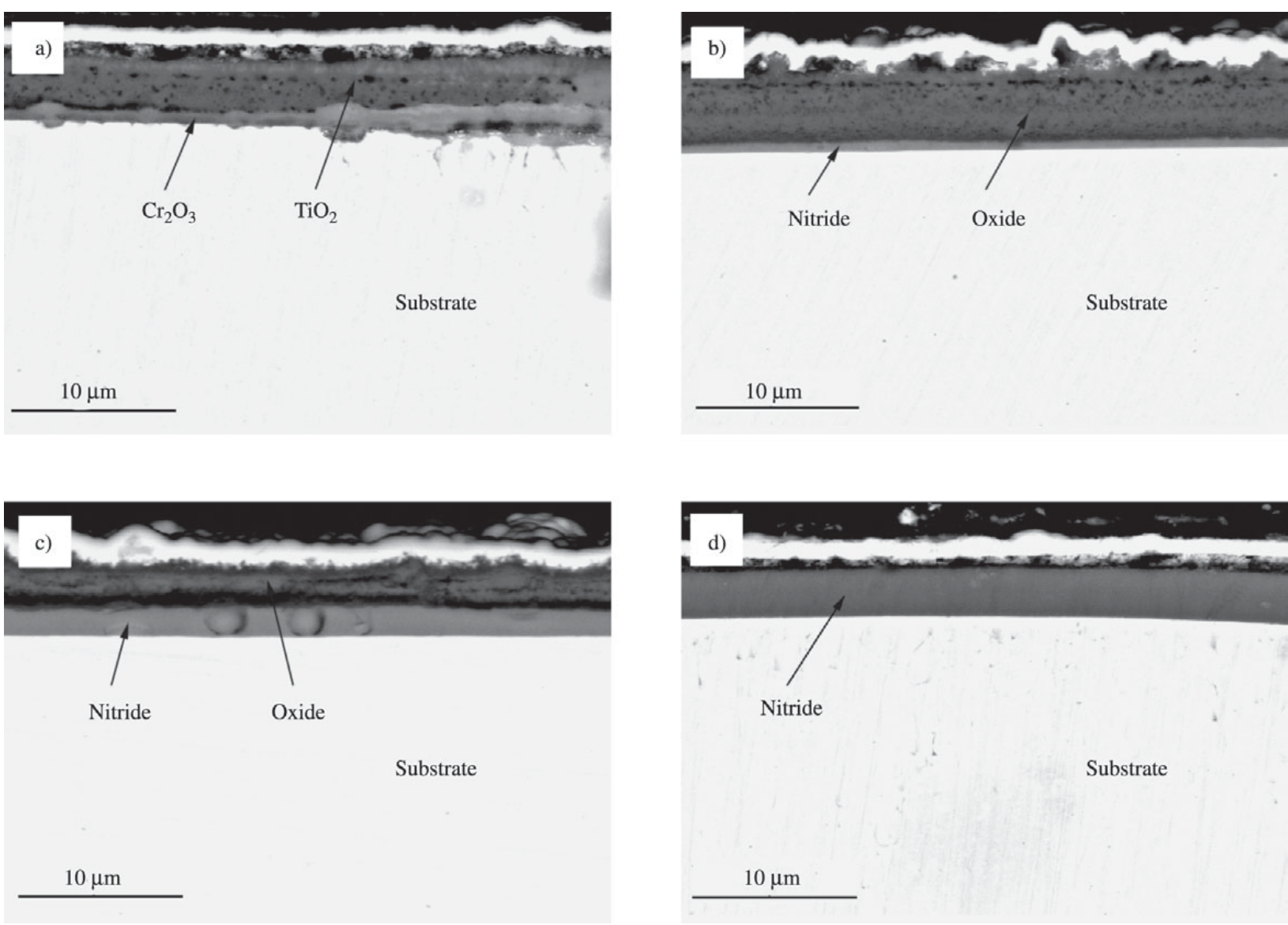

Figure 5. Cross section of coatings $\left(\mathrm{Ti}_{1-\mathrm{x}} \mathrm{Al}_{\mathrm{x}}\right) \mathrm{N}$ after oxidation a) $\mathrm{x}=0$; $\left.\mathrm{b}\right) \mathrm{x}=0.09$; $) \mathrm{x}=0.26$; $\left.\mathrm{d}\right) \mathrm{x}=0.50$.

reactivity of titanium in the coatings ( $\mathrm{Ti}, \mathrm{Al}) \mathrm{N}$ would be suppressed because the valence electron of titanium became more stable in the B1-structure lattice due to the incorporation of $\mathrm{Al}^{10}$.

\subsection{Corrosion of $1 \mathrm{Cr} 11 \mathrm{Ni2}$ W2MoV without and with coatings (Ti,Al)N under synergistic effect of water vapor and $\mathrm{NaCl}$ deposit}

Figure 7 showed the corrosion kinetics of stainless steel $1 \mathrm{Cr} 11 \mathrm{Ni} 2 \mathrm{~W} 2 \mathrm{MoV}$ with and without coatings under the synergetic effect of $\mathrm{NaCl}$ deposit and water vapor. The corrosion of the steel without coating was much severer than that with coatings $\mathrm{TiN}$ or $(\mathrm{Ti}, \mathrm{Al}) \mathrm{N}$. The oxide scale formed on steel $1 \mathrm{Cr} 11 \mathrm{Ni} 2 \mathrm{~W} 2 \mathrm{MoV}$ was rough and irregular, some parts of which peeled or cracked as shown in Fig. 8a. XRD patterns indicated that the outer part of the scale was mainly $\mathrm{Fe}_{2} \mathrm{O}_{3}$. Cross sectional morphology and element mapping (see Fig. 8) ${ }^{1}$ showed that the oxide scale was thick with layered structure. The outer part of the scale was very porous rich in $\mathrm{Fe}$ and followed were successive thinner layers

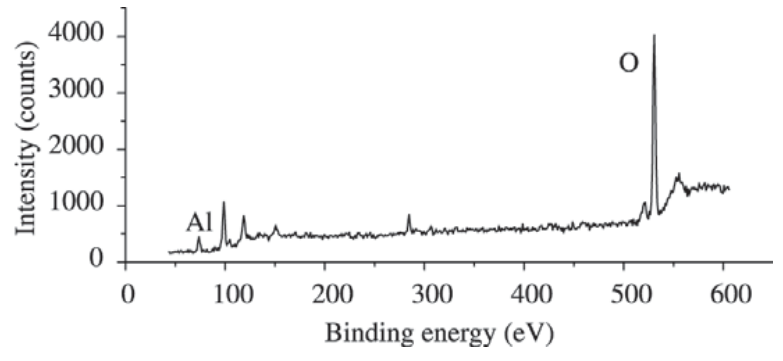

Figure 6. X-ray photoelectron spectra of coating $\mathrm{Ti}_{0.5} \mathrm{Al}_{0.5} \mathrm{~N}$ after oxidation.

rich in $\mathrm{Cr}$ and $\mathrm{Fe}$ alternatively.

A number of nodules with crakes appeared on the TiN surface, which were formed due to the corrosion of the substrate material through pinholes existed in the coating. Oxide scale with finer grains was formed on the coating $\mathrm{Ti}_{0.7} \mathrm{Al}_{0.3} \mathrm{~N}$. Since the corrosion was very slight, mass change 
could hardly be manifested on the kinetic curve. For the coating $\mathrm{Ti}_{0.5} \mathrm{Al}_{0.5} \mathrm{~N}$ there was no obvious mass gain to be detected during the corrosion process and its surface had no significant change after the corrosion.

The $\mathrm{NaCl}$ and water vapor are considered to play an important role in the corrosion process. When corrosion in air or water vapor a protective scale $\mathrm{Cr}_{2} \mathrm{O}_{3}$ formed through the selective oxidation of $\mathrm{Cr}$ of the stee $\mathrm{l}^{12}$. When water vapor and $\mathrm{NaCl}$ deposit were simultaneously presented, the protective oxide scale may be destroyed by reactions such as:

$$
\begin{gathered}
2 \mathrm{NaCl}+1 / 2 \mathrm{Cr}_{2} \mathrm{O}_{3}+\mathrm{H}_{2} \mathrm{O}(\mathrm{g})+3 / 4 \mathrm{O}_{2}(\mathrm{~g})= \\
\mathrm{Na}_{2} \mathrm{CrO}_{4}+2 \mathrm{HCl}(\mathrm{g})
\end{gathered}
$$

The released $\mathrm{HCl}$ will react with the $\mathrm{Fe}$ and $\mathrm{Cr}$ :

$$
\begin{aligned}
& \mathrm{Fe}+2 \mathrm{HCl}=\mathrm{FeCl}_{2}(g)+\mathrm{H}_{2}(g) \\
& \mathrm{Cr}+3 \mathrm{HCl}=\mathrm{CrCl}_{3}(g)+3 / 2 \mathrm{H}_{2}(\mathrm{~g})
\end{aligned}
$$

Since the melting temperature of the metal chlorides is lower than that of the corresponding oxides, and chlorides possess high vapor pressures at a given temperature. Therefore, $\mathrm{FeCl}_{2}$ or $\mathrm{CrCl}_{3}$ may migrate outwards and react with oxygen and water vapor:

$$
\begin{aligned}
& 2 \mathrm{FeCl}_{2}+1 / 2 \mathrm{O}_{2}+2 \mathrm{H}_{2} \mathrm{O}=\mathrm{Fe}_{2} \mathrm{O}_{3}+4 \mathrm{HCl} \\
& 2 \mathrm{CrCl}_{3}+3 \mathrm{H}_{2} \mathrm{O}=\mathrm{Cr}_{2} \mathrm{O}_{3}+6 \mathrm{HCl}
\end{aligned}
$$

And the released $\mathrm{HCl}$ will react with the $\mathrm{Fe}_{2} \mathrm{O}_{3}$ and $\mathrm{Cr}_{2} \mathrm{O}_{3}$ cyclically and the corrosion of the steel is accelerated dramatically.

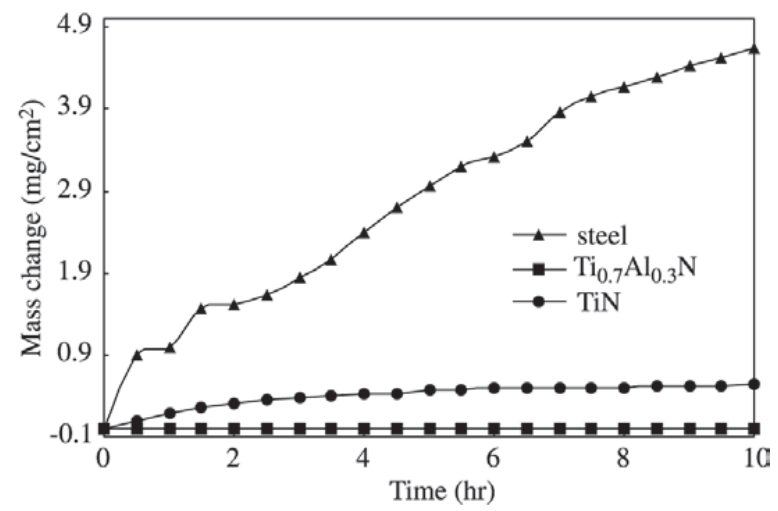

Figure 7. Corrosion kinetics of steel $1 \mathrm{Cr} 11 \mathrm{Ni} 2 \mathrm{~W} 2 \mathrm{MoV}$ coated with coatings $\mathrm{Ti}_{1-x} \mathrm{Al}_{x} \mathrm{~N}$ under synergistic effect of solid $\mathrm{NaCl}$ and water vapor at $600^{\circ} \mathrm{C}$.
At the same time, $\mathrm{NaCl}$ and water vapor may react directly with the substrate such as $\mathrm{Cr}$ and accelerate the corrosion by following reaction:

$$
\begin{gathered}
2 \mathrm{NaCl}+4 \mathrm{H}_{2} \mathrm{O}(\mathrm{g})+3 / 2 \mathrm{O}_{2}(\mathrm{~g})+2 \mathrm{Cr}= \\
1 / 2 \mathrm{Cr}_{2} \mathrm{O}_{3}+\mathrm{Na}_{2} \mathrm{CrO}_{4}+2 \mathrm{HCl}(g)+3 \mathrm{H}_{2}
\end{gathered}
$$

On the other hand, according the analysis of Shu et al. ${ }^{1,3}$, when titanium alloy $\mathrm{Ti} 60$ with $\mathrm{NaCl}$ deposit is exposed to oxygen plus water vapor at high temperature, corrosion is also accelerated according to the following reactions:

$2 \mathrm{NaCl}+\mathrm{Ti}+1 / 2 \mathrm{O}_{2}(g)+\mathrm{H}_{2} \mathrm{O}(\mathrm{g})=\mathrm{TiCl}{ }_{2}+2 \mathrm{NaOH}$

with $\Delta G^{o}=-40.98 \mathrm{~kJ} / \mathrm{mol}$.

$$
\mathrm{TiCl}_{2}+\mathrm{H}_{2} \mathrm{O}(\mathrm{g})=\mathrm{TiO}_{2}+2 \mathrm{HCl}(\mathrm{g})+\mathrm{H}_{2}(\mathrm{~g})
$$

with $\Delta G^{o}=-282.40 \mathrm{~kJ} / \mathrm{mol}$.

$$
\mathrm{Ti}+2 \mathrm{HCl}(g)=\mathrm{TiCl}_{2}(g)+\mathrm{H}_{2}(g)
$$

with $\Delta G^{o}=-102.98 \mathrm{~kJ} / \mathrm{mol}$.

If the similar mechanism can be apply to TiN, the corrosion could occur as following reactions:

$$
\begin{gathered}
2 \mathrm{NaCl}+\mathrm{TiN}+1 / 2 \mathrm{O}_{2}(g)+\mathrm{H}_{2} \mathrm{O}(g)= \\
\mathrm{TiCl}_{2}(g)+2 \mathrm{NaOH}+1 / 2 \mathrm{~N}_{2}(g)
\end{gathered}
$$

with $\Delta G^{o}=239.38 \mathrm{~kJ} / \mathrm{mol}$.

$$
\mathrm{TiCl}_{2}+\mathrm{H}_{2} \mathrm{O}(\mathrm{g})=\mathrm{TiO}_{2}+2 \mathrm{HCl}(\mathrm{g})+\mathrm{H}_{2}(\mathrm{~g})
$$

with $\Delta G^{o}=-282.4 \mathrm{~kJ} / \mathrm{mol}$.

$$
\begin{aligned}
& \mathrm{TiN}+2 \mathrm{HCl}(\mathrm{g})= \\
& \mathrm{TiCl}_{2}(\mathrm{~g})+2 \mathrm{NaOH}+\mathrm{H}_{2}(g)+1 / 2 \mathrm{~N}_{2}(g)
\end{aligned}
$$

with $\Delta G^{o}=179.39 \mathrm{~kJ} / \mathrm{mol}$.

Herewith it can be seen that the thermodynamic driving force of reaction (10) and (12) is much smaller than that of reaction (7) and (9). Reaction (10) and (12) can hardly progress since the thermo-dynamical balance will be quickly reached. So the simultaneous presence of water vapor and $\mathrm{NaCl}$ deposit have no obvious effect on the corrosion of nitrides. Even though there is no distinct difference between the corrosion-resistance induced by the synergistic effect of water vapor and $\mathrm{NaCl}$ deposit and the oxidation-resistance in air for nitrides. However the coatings ( $\mathrm{Ti}, \mathrm{Al}) \mathrm{N}$, especially those with high $\mathrm{x}$ values showed much better corrosion re- 

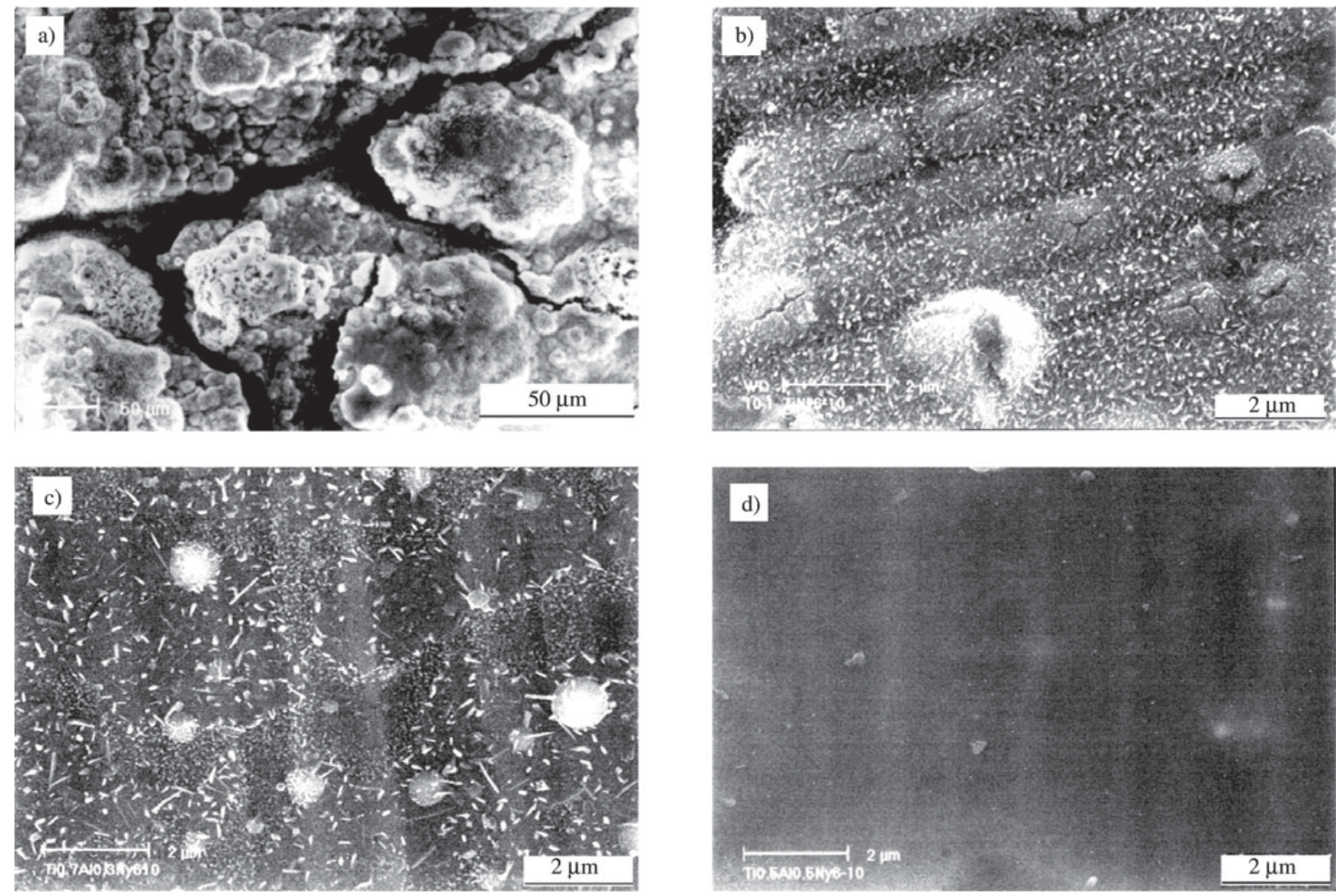

Figure 8. Surface Morphologies of $1 \mathrm{Cr} 11 \mathrm{Ni} 2 \mathrm{~W} 2 \mathrm{MoV}$ steel with coatings after $10 \mathrm{~h}$ corrosion at $600{ }^{\circ} \mathrm{C}$ under synergistic effect of $\mathrm{NaCl}$ and water vapor a) bare steel; b) $\mathrm{TiN} ; \mathrm{c}) \mathrm{Ti}_{0.7} \mathrm{Al}_{0.3} \mathrm{~N} ;$ d) $\mathrm{Ti}_{0.5} \mathrm{Al}_{0.5} \mathrm{~N}$.

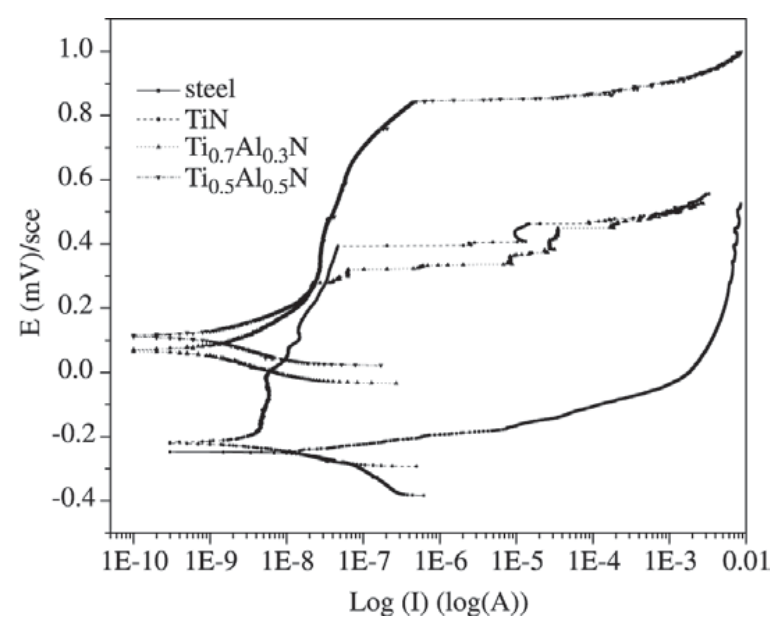

Figure 9. Polarization curves of steel without and with coatings in solution $0.5 \mathrm{M} \mathrm{NaCl}$ at ambient temperature.

sistance than TiN. For which the reason may be the preferential oxidation of $\mathrm{Al}$ during the very beginning stage of the corrosion, it was which seals pinholes or defects in the coating to prevent the occurrence of any localized nodules-like corrosion as shown in Fig. 8b.

\subsection{Wet corrosion performance in $\mathrm{NaCl}$ solution at ambient temperature}

Potentiodynamic polarization curves in $0.5 \mathrm{M} \mathrm{NaCl}$ solution (see Fig. 9) indicated that in comparison with the bare steel, the free corrosion potential of nitride coatings shifted to far more positive, especially those with $\mathrm{Al}$ additions and they also showed a passivation-like behavior with a wide range of potential. Of course the steel was very susceptible to pitting corrosion in the solution. The fact seemed also important, while in the real service the material may suffer from wet corrosion, especially in the shutdown period of the facility.

\section{Conclusions}

With addition of $\mathrm{Al}$, the hardness and adhesive strength of coatings ( $\mathrm{Ti}, \mathrm{Al}) \mathrm{N}$ may be enhanced, which reach an optimum by certain amount of $\mathrm{Al}$ and then decreased.

The oxidation resistance of coatings $(\mathrm{Ti}, \mathrm{Al}) \mathrm{N}$ is enhanced with increasing $\mathrm{Al}$ at temperatures up to $800^{\circ} \mathrm{C}$ companying with formation of an external scale rich in alumina. $\mathrm{Al}$ addition is beneficial also to coatings $(\mathrm{Ti}, \mathrm{Al}) \mathrm{N}$ to protect the 
steel $1 \mathrm{Cr} 11 \mathrm{Ni} 2 \mathrm{~W} 2 \mathrm{MoV}$ against the corrosion induced by solid $\mathrm{NaCl}$ in wet oxygen at $600{ }^{\circ} \mathrm{C}$ and also the wet corrosion in $\mathrm{NaCl}$ solution at ambient temperature.

Therefore, due to the versatility of coatings ( $\mathrm{Ti}, \mathrm{Al}) \mathrm{N}$, it is expected that the chemical composition and phase constituent of the coatings ( $\mathrm{Ti}, \mathrm{Al}) \mathrm{N}$ may be tailored to reach an optimal combination of physical and chemical properties to meet the requirements of service.

\section{Acknowledgement}

The project supported by NSF China under grants № 59625101 and 59971052.

\section{References}

1. Shu, Y.H. Corrosion behavior of some metals and coatings under the synergetic effect of solid $\mathrm{NaCl}$ and water vapor at $500-700{ }^{\circ} \mathrm{C}$, Doctoral Thesis, The Institute of Corrosion and Protection of Metals. June 1999.

2. Shu, Y.H.; Wang, F.H.; Wu, W.T. Oxid. Met., v. 51, n. 1/
2, p. 97-110, 1999.

3. Y. H. Shu, F. H. Wang, and W. T. Wu, Oxid. Met., v. 54, n. 5/6, p. 457-471, 2000.

4. Wu, W.T.; Wang, F.H.; Shu, Y.H. in High Temp. Corros. Protec 2000, edited by T. Narita et. al., Science Review, p. 239, 2000.

5. Ikeda, T.; Satoh, H. Thin Solid Films, v. 195, p. 99-110, 1991.

6. Cselle, T.; Barimani, A. Surf. Coat. Technol. V. 76/77, p. 712-718, 1995.

7. Li, M.S. Preparation and performance of $(\mathrm{Ti}, \mathrm{Al}) \mathrm{N}$ and (Ti,Al,Y)N coatings deposited by arc ion plating, Doctoral Thesis, The Institute of Corrosion and Protection of Metals. June 2002.

8. Burg, S.; Blom, H.O.; Larsson, T.; Nender, C. J. Vac. Sci. Technol., A5 (2), p. 202-207, 1987.

9. Konig, U. Surf. Coatings Technol., v. 33, p. 91-103, 1987. 10. Zhou, M.; Makino, Y.; Nose, M.; Nogi, K. Thin Solid Films, v. 339, p. 203-208, 1999.

11. Shu, Y.H.; Wang, F.H.; Wu, W.T. Oxid. Met., v. 52, n. 5/ 6, p. 463-473, 1999. 